\title{
Crude Protein Electrophoresis of Three Varieties of Impatiens balsamina L. (Balsalminaceae) in Obafemi Awolowo University, Ile-Ife, Osun State, Nigeria
}

\author{
Teniola, K. A., Bolaji, A. O., Ojo, R. A., Folorunso, A. E. \\ * Obafemi Awolowo University, Department of Botany, Ile-Ife, Osun State, Nigeria \\ DOI: 10.29322/IJSRP.11.06.2021.p11476 \\ http://dx.doi.org/10.29322/IJSRP.11.06.2021.p11476
}

\begin{abstract}
Crude protein electrophoresis of some varieties of Impatiens balsamina in Obafemi Awolowo University was carried out with a view to investigate their taxonomic relationship and also to verify their circumscription. The seeds and leaves samples obtained from mature plants of the varieties studied were subjected to sodium diodecyl sulphate-polyacrylamide gel electrophoresis (SDS-PAGE) following standard methods. The results obtained showed that the seed and leaf samples of the Impatiens balsamina varieties studied differ in their protein content with the seeds having more protein content but the leaves having more protein bands than the seeds. A close examination of the protein bands revealed that in the seeds and leaf studied, there were both qualitative and quantitative variations regarding the quantity (number), position and staining intensity of the protein bands. Interspecific and species-specific bands were recorded. The presence of common protein bands among the species may be an evidence of the evolutionary origin of the Impatiens balsamina varieties studied. Results obtained revealed close relationship and distinctness with broad based relationship occurring among the three varieties of Impatiens balsamina studied and could therefore be important in their infra-specific relationship.
\end{abstract}

Index Terms- leaf protein, seed protein, electrophoretic study, protein bands, taxonomic relationship

\section{INTRODUCTION}

$I^{\prime \prime}$ mpatiens balsamina is an ornamental plant in the family Balsaminaceae (Gardeners, 2017). The flowers can be red, purple, white or pink (Taha et al., 2009). It is a popular ornamental plant that has been widely introduced across the tropical and subtropical regions of the world (Flora Mesoamericana, 2018; PIER, 2018; USDA-ARS, 2018).

The genus Impatiens has shown much diversity in its seed morphological characters, particularly the seed coat patterns, which have proved very useful in the taxonomic and phylogenetic delimitation of the species (Lu and Chen, 1991; Somg et al., 2005; Utami and Shimizu, 2005). The micro and macro morphological characters of the seeds also provide additional taxonomic character in the intricate genus Impatiens where character differences are not much and are therefore difficult to delimit (Lu and Chen, 1991; Song et al., 2005). Different parts of the plant were reported to have ethnobotanical importance and have been used in the treatment of various ailments. The juice from the leaves is used to treat warts and snakebite, while the flowers are applied to burns (Wang et al., 2009; Binorkar et al., 2012). The seed oil can be used for burning lamps and in surface coating industry (Chen et al., 2010). The aerial parts of plant are used for treatment of articular rheumatism, bruises and beriberi in Chinese herbal medicine (Mishra et al., 2012).

Protein electrophoresis has been regarded as one of the useful tools for resolving systematic problems in situations where morphological character are felt inadequate to make taxonomic decisions (Suranto, 2002). It has become an additional tool to unravel taxonomic and phylogenetic problems (Azeez and Morakinyo, 2004) and has been used to characterize and delimit species by various researchers (Adedeji and Adewale, 2006; Folorunso et al., 2006; Radwan et al., 2013; Johnson, 2016; Oladejo et al., 2019).

Due to the complex taxonomic status of Impatiens balsamina varieties, this study was carried out with a view to investigate the taxonomic relationship among the varieties studied and also to clarify their circumscription..

\section{MATERIALS AND METHODS}

Crude protein was extracted from the seed and leaf samples of mature plant varieties (red petal, pink petal and white petal) of Impatiens balsamina obtained from the Department of Botany, Obafemi Awolowo University, Ile- Ife (70 31' $8^{\prime \prime} \mathrm{N} 4^{0} 31$ ' 34"E), Osun State, Nigeria following the method of Adedeji and Illoh (1995). SDS-PAGE was carried out on each protein sample using standard method. The protein bands of the gel were analysed by measuring their distance on the gel from the origin; while the coefficient of similarity among the bands was calculated using the Sokal and Sneath coefficient (Sokal and Sneath, 1963) as follows:

Coefficient of similarity $(\mathrm{CS})=\frac{a}{a+b+c}$ 
Where CS $=$ coefficient of similarity between species I and II

$\mathrm{a}=$ number of bands common to I and II

$\mathrm{b}=$ number of bands in I not in II

$\mathrm{c}=$ number of bands in II not in I

The protein concentration of each of the seeds and leaves of Impatiens balsamina studied was determined following the method of Bradford (1976) with Bovine Serium Albumin (BSA) as standard at concentration 10 $\mu \mathrm{g} / \mathrm{ml}$.

\section{RESULTS}

The three varieties of Impatiens balsamina studied is shown in Plate 1. The result obtained in this study revealed that the seed protein and leaf protein samples of the Impatiens balsamina varieties studied differ in their protein concentration (Table 1). The protein content was higher in the seeds than in the leaves. The white seed had the highest protein content $(19.8 \mathrm{mg} / \mathrm{g})$, followed by the red seed (15.9 $\mathrm{mg} / \mathrm{g}$ ) and then the pink seed $(5.4 \mathrm{mg} / \mathrm{g}$ ) which had the least protein content. In the leaf protein samples (Table 1), the red variety had the highest protein content $(6.0 \mathrm{mg} / \mathrm{g})$, followed by the pink variety $(4.0 \mathrm{mg} / \mathrm{g})$ and then the white variety $(2.0 \mathrm{mg} / \mathrm{g})$ with the least protein content.

The electrophoregram of the three varieties of Impatiens balsamina studied is represented in Figure 1; while the schematic diagram of the electrophoregram is shown in Figure 2. A close examination of the bands revealed that in the seed protein samples and leaf protein samples studied, there were both qualitative and quantitative variations regarding the quantity (number), position and staining intensity of the bands, with more bands occuring in the leaf protein samples than the seed protein samples (Figure 1 and 2).

The SDS-PAGE of the seed protein of the three varieties studied showed distinct electrophoretic banding patterns that led to the detection of a total of twenty-four (24) bands (Table 2). Most (fourteen) of the bands were found to be intermediate moving bands (2.0 $\mathrm{cm}-3.9 \mathrm{~cm}$ ), while ten were fast moving bands $(4.0 \mathrm{~cm}-6.0 \mathrm{~cm}$ ). No slow moving band was found (Table 2).

The SDS-PAGE of the leaf protein of the three varieties studied showed distinct electrophoretic banding patterns that led to the detection of a total of forty-six (46) bands (Table 3). Most (22) of the bands were intermediate moving bands $(2.0 \mathrm{~cm}-3.9 \mathrm{~cm})$, eighteen (18) were fast moving bands $(4.0 \mathrm{~cm}-6.0 \mathrm{~cm})$, while six $(6)$ were slow moving bands $(0 \mathrm{~cm}-1.9 \mathrm{~cm})$.

In the seed protein samples of Impatiens balsamina varieties studied, six generic bands occured at 5.4, 4.9, 4.1, 3.9, 3.4 and 3.6 having the same intensities and combination of bands (Figure 1 and 2). The red variety had three unique bands at 2.5, 2.75 and 4.25 with the same intensity, position and combination of bands; while the pink and white variety had no unique bands (Figure 1 and 2). The pink and the white varieties had seven common bands with similar intensity; while the red variety had seven bands in common with the pink variety with same intensity. The highest percentage of similarity (100\%) was found between the pink variety and the white variety of Impatiens balsamina studied (Table 4).

In the leaf protein samples of the Impatiens balsamina varieties studied, eight generic bands were found at $0,1.8,2.0,2.25,2.9,3.2$, 3.25-6.0. All these varied slightly in intensities (Figure 2). The red and the pink varieties had the highest number of common bands (ten). The red variety had unique bands at 2.6, 2.7 and 2.75. The white variety had unique bands at 3.7, 4.0, 4.9, 5.2, and 5.45. The pink variety did not show unique bands (Figures 1 and 2). The white variety had 8 bands in common with the red variety and also 9 bands in common with the pink variety (Figure 2). The highest percentage of similarity (67\%) was found between the red varieties and the pink varieties of Impatiens balsamina studied (Table 5).
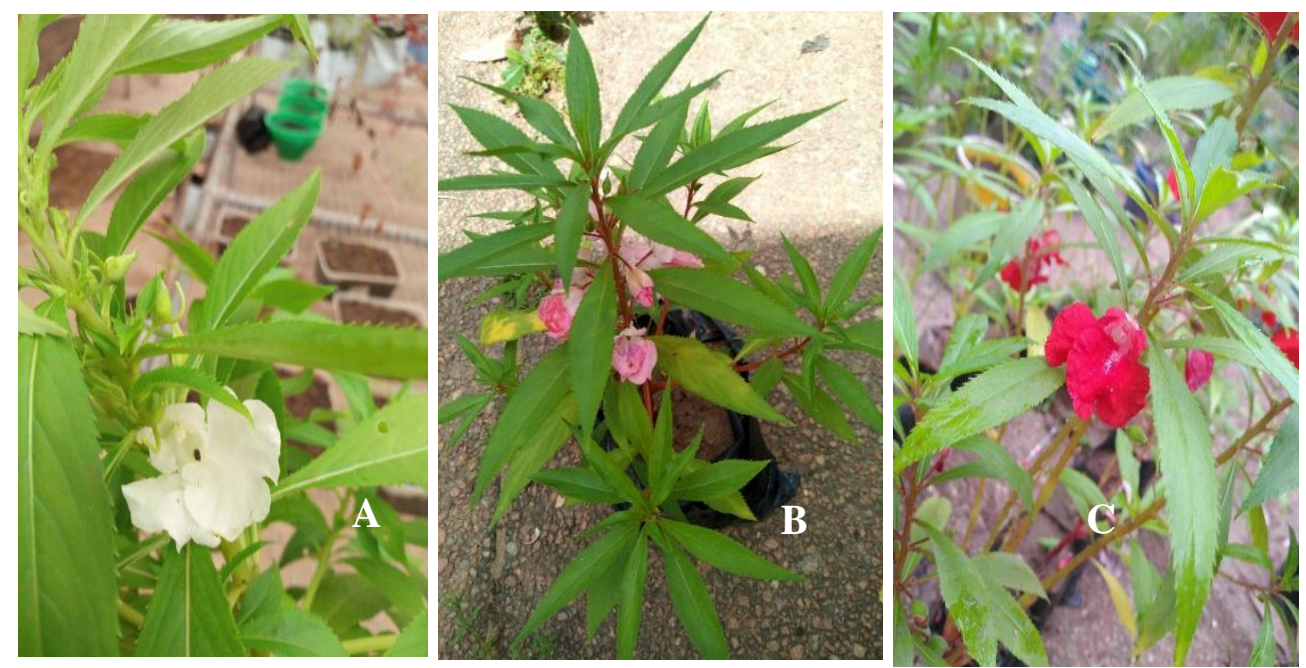

Plate 1: The varieties of Impatiens balsamina studied.

A: Red Impatiens balsamina; B: White Impatiens balsamina; C: Red Impatiens

Table 1: Protein concentration of the seed and the leaf samples of the three varieties of Impatiens balsamina studied 


\begin{tabular}{l|l}
\hline Samples & Amount of protein per gram of sample (mg/ml) \\
\hline I. balsamina seed (Pink variety) & 5.4 \\
I. balsamina seed (Red variety) & 15.8 \\
I. balsamina seed (White variety) & 19.8 \\
I. balsamina leaf (Pink variety) & 4.0 \\
I. balsamina leaf (Red variety) & 6.0 \\
I. balsamina leaf (White variety) & 2.0 \\
\hline
\end{tabular}

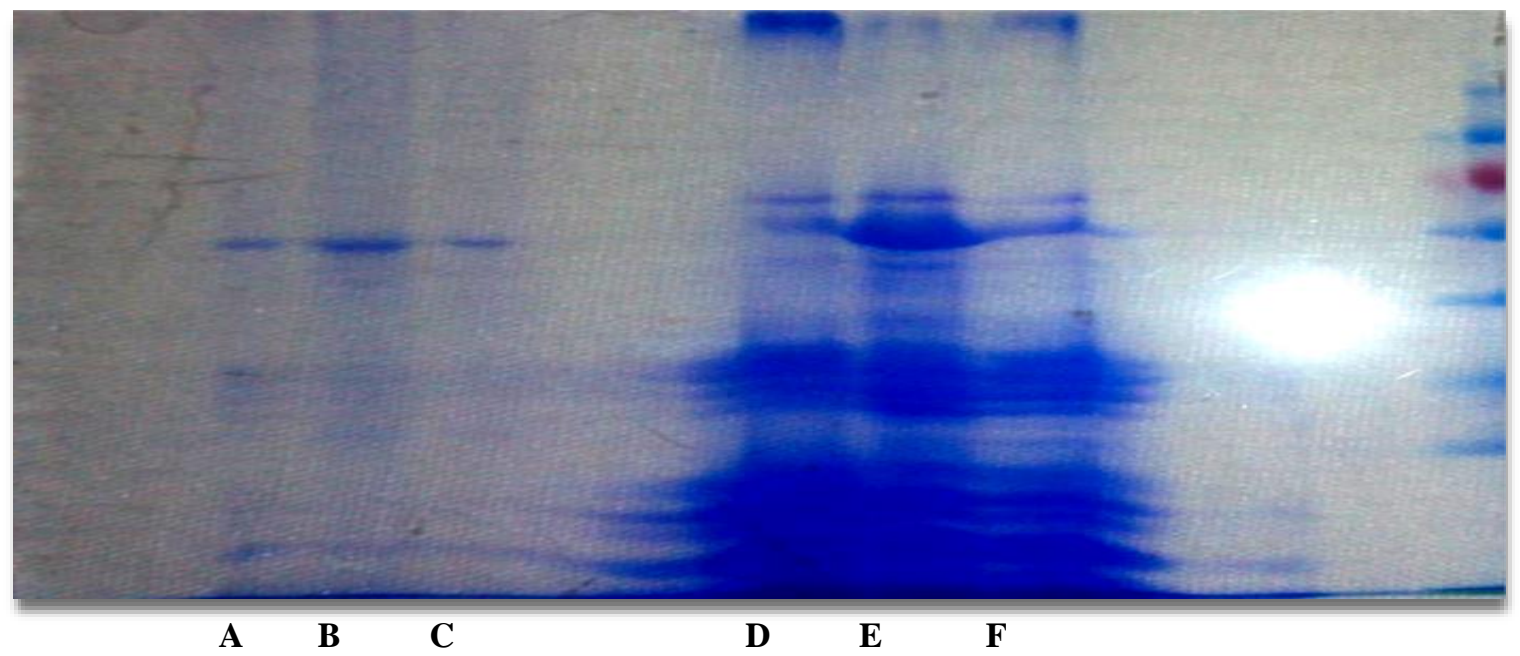

Figures 1: Electrophoregram of the seed and leaf protein of the three varieties of Impatiens balsamina studied

Legends: A: seed protein bands of the pink variety; B: seed protein bands of the red variety; C: seed protein bands of the white variety; D: leaf protein bands of the pink variety; E: leaf protein bands of the red variety; F: leaf protein bands of the white variety.

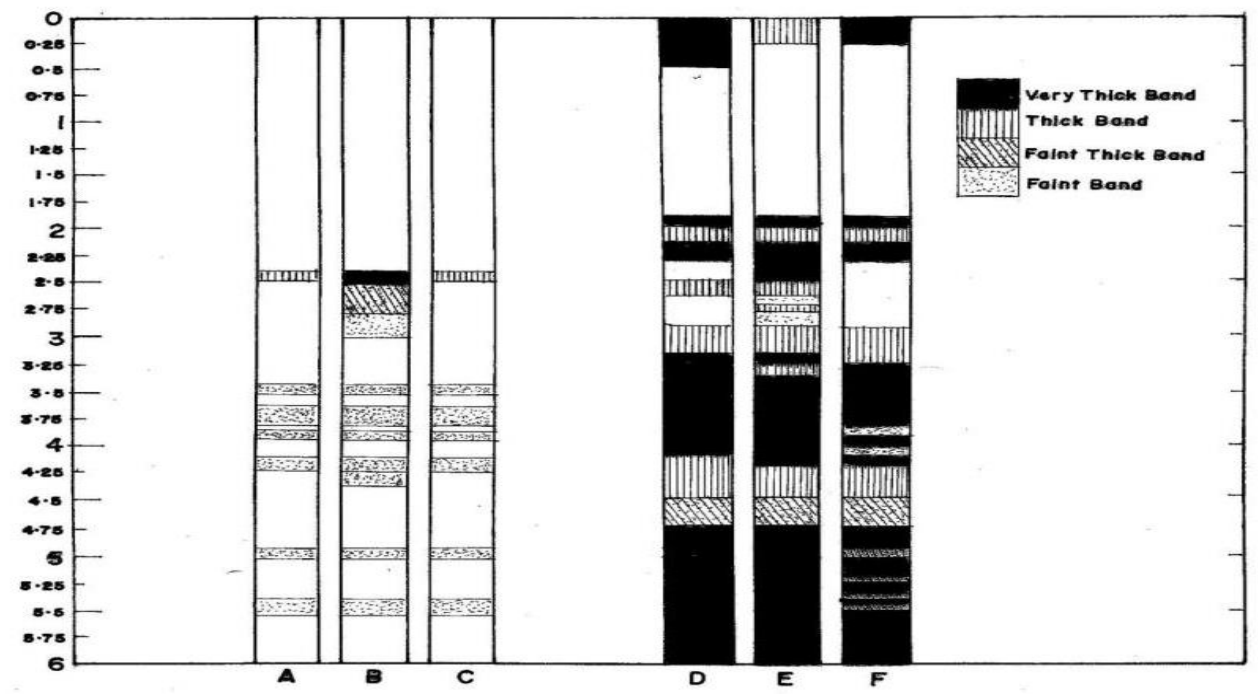

Figure 2: Schematic diagram of the electrophoregram of the seed and leaf proteins of the three Impatiens balsamina varieties studied

Legends: A represent pink seed; B represent red seed; C represent white seed; D represent pink leaf; E represent red leaf; F represent white leaf. 
Table 2: Relative mobility of bands in the seed protein of Impatiens balsamina varieties studied

\begin{tabular}{l|l|l|l|l}
\hline Seed protein sample & Total number of bands & $\begin{array}{l}\text { Fast } \\
\mathbf{( 4 . 0 - 6 . 0 )}\end{array}$ & bands & $\begin{array}{l}\text { Intermediate bands } \\
\mathbf{- 3 . 9})\end{array}$ \\
\hline A (pink variety) & 7 & 3 & 4 & $\begin{array}{l}\text { Slow bands } \\
(\mathbf{0}-\mathbf{1 . 9})\end{array}$ \\
B (red variety) & 10 & 4 & 6 & 0 \\
C (white variety & 7 & 3 & 4 & 0 \\
Total & 24 & 10 & 14 & 0 \\
\hline
\end{tabular}

Table 3: Relative mobility of bands in the leaf protein of Impatiens balsamina varieties studied

\begin{tabular}{|c|c|c|c|c|}
\hline Leaf protein sample & Total number of bands & $\begin{array}{ll}\text { Fast } & \text { bands } \\
(4.0-6.0) & \\
\end{array}$ & $\begin{array}{l}\text { Intermediate bands }(2.0 \\
-3.9)\end{array}$ & $\begin{array}{l}\text { Slow bands } \\
(0-1.9)\end{array}$ \\
\hline $\mathrm{D}$ (pink variety) & 10 & 3 & 5 & 2 \\
\hline E (red variety) & 15 & 3 & 10 & 2 \\
\hline F (white variety) & 21 & 12 & 7 & 2 \\
\hline Total & 46 & 18 & 22 & 6 \\
\hline
\end{tabular}

Table 4: Coefficient of similarity of the seed protein samples of Impatiens balsamina varieties studied

\begin{tabular}{l|l|l|l}
\hline Varieties of Impatiens balsamina seed & A & B & C \\
\hline A (Pink variety) & - & $70 \%$ & $100 \%$ \\
B (Red variety) & $70 \%$ & - & $70 \%$ \\
C (White variety) & $100 \%$ & $70 \%$ & - \\
\hline
\end{tabular}

Table 5: Coefficient of similarity of the seed protein samples of Impatiens balsamina varieties studied

\begin{tabular}{l|l|l|l}
\hline Varieties of Impatiens balsamina leaf & D & E & F \\
\hline D (Pink variety) & - & $67 \%$ & $52 \%$ \\
E (Red variety) & $67 \%$ & - & $45 \%$ \\
F (White variety) & $52 \%$ & $45 \%$ & - \\
\hline
\end{tabular}

\section{DISCUSSION}

Electrophoresis is a method of separting proteins based on their physical properties (Theodore et al., 2005) and has been used by many researchers in the taxonomic delimination of species. Protein content was generally higher in the seeds than in the leaves of the Impatiens balsamina studied, with the seeds of the white variety having the highest protein content while those of the pink variety had the lowest protein content.

In the leaf samples, protein content was highest in the red variety and lowest in the white variety. This suggest that the seeds of the Impatiens balsamina studied was a better source of protein than the leaves although there is no known report yet as to whether the plant is safe for human consumption. Protein is an essential component of the human diet needed for the replacement of dead tissues and for the supply of adequate amount of required amino acids (Igile et al., 2013).

Although the protein content was higher in the seeds than the leaves, the electrophoregram showed that the leaf samples had more protein bands and revealed more details as regards to the presence of unique bands and common bands among the three varieties of Impatiens balsamina studied. This may be due to limited proteolysis of the dry seeds used for the electrophoretic study. Shutov et al., (2003) explained that although storage proteins are protected from early degradation, there is limited proteolysis in dry seeds.

The presence of generic bands across the varieties studied when seed proteins were used $(5.4 \mathrm{~cm}, 4.9 \mathrm{~cm}, 4.1 \mathrm{~cm}, 3.9 \mathrm{~cm}, 3.6 \mathrm{~cm}$ and $3.4 \mathrm{~cm})$ and when leaf proteins were used $(0 \mathrm{~cm}, 1.8 \mathrm{~cm}, 2.0 \mathrm{~cm}, 2.25 \mathrm{~cm}, 2.9 \mathrm{~cm}, 3.2 \mathrm{~cm}$ and $3.25 \mathrm{~cm}-6.0 \mathrm{~cm})$ is an indication of their close genetic affinity and common ancestry. Akinwusi and Illoh, (1995) attributed the appearance of a common band in all individual in a population to the fact that the gene coding for the enzyme or protein does not vary. The presence of the generic bands implies that they have the same evolutionary origin and this can be seen phenotypically in the shape of their flowers and leaves which are the same. 
The bands at $2.5 \mathrm{~cm}, 2.75 \mathrm{~cm}$, and $4.25 \mathrm{~cm}$ in the red variety (where seed proteins are used) are diagnostic and could be used to delimit the red species. Where leaf protein samples are used, the red varieties can be delimited by the unique bands at $2.6 \mathrm{~cm}, 2.7 \mathrm{~cm}$ and 2.75 $\mathrm{cm}$. When leaf protein samples were used, the white varieties of Impatiens balsamina have unique bands at $3.7 \mathrm{~cm}, 4.0 \mathrm{~cm}, 4.9 \mathrm{~cm}, 5.2$ $\mathrm{cm}$, and $5.45 \mathrm{~cm}$ which are diagnostic and can be used to delimit the white varieties. The unique bands are species-specific bands which can be useful in the taxonomic identification of the Impatiens balsamina studied. This report is in line with the findings of Mohammed et al., (2006) on members of Aracaceae. According to Cronquist (1968), the presence of a character is of greater taxonomic importance than its absence. Therefore the presence of the unique bands could be useful in the delimiting of the varieties of Impatiens balsamina studied.

The presence of common bands in red and pink varieties when the seed protein samples were used suggest that the genes for the bands are conserved, this may be adaptive gene which had evolved, become dispersed and fixed in the varieties over evolutionary time. It also an evidence of phenotypic plasticity and it could be as a result of the genotype-environment interaction between the pink and white varieties of the Impatiens balsamina studied.

The highest percentage of similarity (100\%) was found between the pink and white varieties when seed proteins were used (Table 4) which was a clear indication that they were phylogenetically related than the red variety. In contrast to this, the least percentage of similarity was observed between the red variety and the white variety when leaf protein samples were used, suggest that they evolved along different evolutionary trends (Azeez \& Morakinyo, 2004).

Results from this study implied that the three varieties of Impatiens balsamina studied came from the same parental stock but had a convergent evolution, thereby making it possible for character traits to be shared in common. This is further corroborated by the assertion of Gottlieb (1971) that when a band appear in all individuals in a population, it is assumed that the gene which codes the enzyme or protein does not vary.

\section{CONCLUSION}

In conclusion, this electrophoretic study revealed the presence of common protein bands among the varieties Impatiens balsamina studied which may be an evidence of their evolutionary origin. The variation observed in the distribution of protein bands in the varieties were species-specific. The seed and leaf protein electrophoresis appeared to demonstrate close relationship and distinctness with broad based relationship occurring between the three varieties of Impatiens balsamina studied which could therefore be important intheir infra-specific relationship.

\section{ACKNOWLEDGMENT}

The authors wish to appreciate the laboratory staff members of the Department of Biochemistry amd Molecular Biology, Obafemi Awolowo university, Ile-Ife, Nigeria, for their assistance in providing some of the laboratory materials used for this study.

\section{REFERENCES}

Adedeji, O.. and Adewale, I.O. (2006). An electrophoresis Study of Crude Protein Diversity in the Seeds of the Genus Emila cass in Nigeria. Science Focus 11(2): 179182.

Adedeji, O. and Illoh, H.C. (1995). Crude protein electrophoresis of seeds of some species of Hibiscus. Nigerian Journal of Botany 8: 71-76.

Akinwusi, O. and Illoh, H.C. (1995). Crude Protein Electrophoresis of seeds of some species of Hibiscus. Nigerian Journal of Botany 8: 71-76.

Azeez, M.A. and Morakinyo, J.A. (2004). Electrophoretic characterization of crude leaf proteins in lycopersicon and Trichosanthes cultivar. African Journal of Biotechnology 3(11): 585-587.

Binorkar, S.V. and Jani, D.K.. (2012). Profile of medicinal plants with Antiophidian property. Journal of Pharmaceutical and Scientific Innovation 1(5): 13-20.

Bradford, M., 1976. A rapid and sensitive method for the quantitation of microgram quantities of protein utilizing the principle of protein-dye binding. Analytical Biochemistry 72(1-2): 248-254

Chen, X.M., Qian, S.H.and Feng, F. (2010). Two new tetrahydronaphthalenes from the stem of Impatiens balsaminal L. Chinese Chemical Letters 21: 440-442.

Cronquist, A. (1968). The evolution and classification of flowering plants. Thomas Nelson and sons Ltd: London. pp. 49-121.

Flora Mesoamericana. 2018. Flora Mesoamericana. Missouri Botanical Garden, St. Louis, Missouri, USA. http://www.tropicos.org/Project/fm.

Folorunso, A.E., Awelewa, O. A. and Adewale, I.O. (2006). Comparative Study of Protein Profile of Leaves of Wild Manihot glaziovii Mueller and the Cultivated Species, Manihot esculenta Crantz by SDS-polyacrylamide Gel Electrophoresis. International Journal of Agricultural Research 1(1): 53-57.

Gardeners. (2017). Plant Botanical Names. http://gardnersnet.com/gardening/plantbotanicalnames.htm

Gottlieb L.D. 1971. Gel electrophoresis: New approach to the study of evolution. Biosci., 21(18): 939-944.

Igile, G.O., Iwara, I.A., Mgbeje, B.I., Uboh, F.E. and Ebong, P.E. (2013). Phytochemical, proximate and nutrient composition of Vernonia calvaona Hook (Asteraceae): A green-leafy vegetable in Nigeria. Journal of Food Research 2(6): 111-122.

Johnson, M. (2016). Inter-specific Variation Studies among Nephrolepis using SDS-PAGE. Journal of Pharmacognosy and Natural Product 2(1): 1-3.

Lu, Y.Q. and Chen, Y.L. (1991). Seed Morphology of Impatiens L. (Balsaminaceae) and its taxonomic significance. Acta Phytotaxonomica Sinica $29: 252-257$.

Mishra, R.K., Patel, S.P., Srivastava, A., Vashistha, R.K., Singh, A. and Puskar, A.K. (2012). Ethnomedicinally important plants of Panchmarhi region, Madhya Pradesh, India. Nature and Science 10(4): 22-26.

Mohammed, T.R., Khalifa, S.K., Salah el-Dine, R.M. (2006). Leave protein electrophoretic profile and chromosome numbers of some Aracaceae. International Journal of Agriculture and Bioogy 8(2): 231-234.

Oladejo, A.S., Bolaji, A.O., Obisesan, I.O. and Omitogun, O.G. (2019). SDS-PAGE characterization of some elite cowpea (Vigna unguiculata L.Walp) varieties. Nigerian Journal of Biotechnology36(2): 45-51.

PIER. 2018. Pacific Islands Ecosystems at Risk. Honolulu, Hawaii: HEAR, University of Hawaii. http://www.hear.org/pier/index.html 


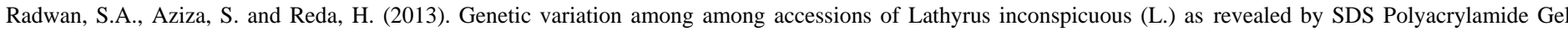
Electrophoresis. Acta Agriculturae Slovenica 101(1): 21-30.

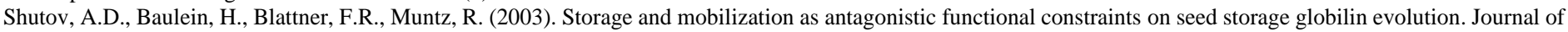
Experimental Botany 54(388): 1645-1654.

Sokal, R.R. and Sneath, P.H. (1963). Principles of Numerical Taxonomy. San Francisco. Freeman.

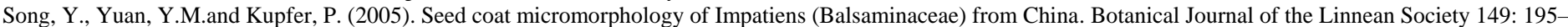
208.

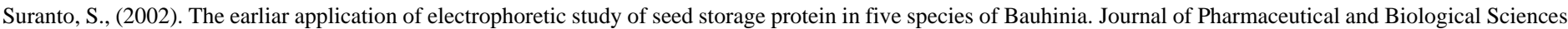
4(2): 8-4.

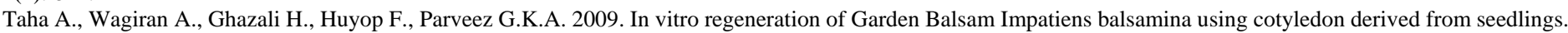
Biotechnology 8(1): 44-52.

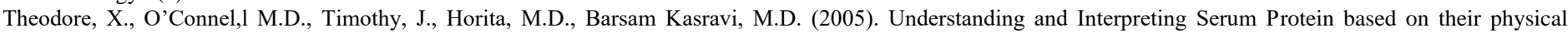
properties. American Family Physician 71(1): 105-112.

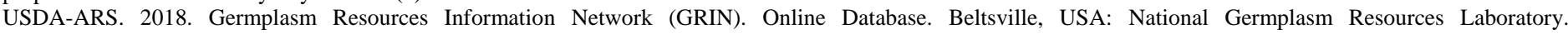
http://www.ars-grin.gov/cgi-bin/npgs/html/tax_search.pl

Utami, N. and Shimizu, T. (2005). Seed morphology and classification of Impatiens (Balsaminaceae). Blumea 50: $447-456$.

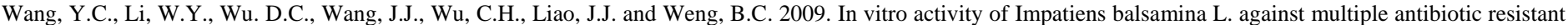
Helicobacter pylori. - American Journal of Chinese Medicine 37(4): 713-722.

\section{AUTHORS}

First Author - Kareemat Abeo Teniola, BSc. Botany, kareeprecious@ gmail.com

Second Author - Abolade Oluremi Bolaji, PhD. Botany, abolaji@ oauife.edu.ng

Third Author - Ruth Adeola Ojo, BSc. Botany, ojoruth9@ gmail.com

Fourth Author - Abayomi Ezekiel Folorunso, Professor of Botany, afolorun@ oauife.edu.ng

Correspondence Author - Abolade Oluremi Bolaji, abolaji@ oauife.edu.ng, aboladebolaji2017@gmail.com, Department of Botany, Obafemi Awolowo University, Ile-Ife, Nigeria. 